\title{
THIRD PARTY FUNDS, NUMBER OF CAPITAL, AND NON-PERFORMING FINANCING TO THE NUMBER OF MUDHARABAH FINANCING IN INDONESIA'S SHARIA BANKING
}

\author{
Muhammad Iqbal Surya Pratikto \\ Post Graduate Universitas Airlangga \\ Muhammadiqbalsurya@gmail.com
}

\author{
Ririn Tri Ratnasari \\ Post Graduate Universitas Airlangga \\ ririnsari@feb.unair.ac.id
}

\begin{abstract}
This study aims to determine and analyse the effect of DPK, Total Capital, and NPF on the amount of mudharabah financing in sharia banks in Indonesia. The discussion in this research study is how the influence of the variables of DPK, Total Capital, and NPF impact on the variable amount of financing. The research method used was quantitative by using secondary data obtained from the statistics of shariah banking in Indonesia. The technique of data analysis in this research was the Ordinary Least Square (OLS) analysis tool. The results of this study found that the DPK has a positive influence on the variable amount of mudharabah financing, Total Capital has no effect on the variable amount of mudharabah financing, and NPF has a positive effect on the variable amount of mudharabah financing. Although the amount of capital has no significant effect on the amount of mudharabah financing, $81.9 \%$ of the variations in Mudharabah Financing variables are explained by the Third Party Funds (DPK), Total Capital (CAR) and Non Performing Financing (NPF) variables.
\end{abstract}

Keyword: Third Party Funds, Number of Capital, Non Performing Financing, Number of Mudharabah

\section{INTRODUCTION}

Sharia Bank is a financial institution whose main business is to provide credit, financing and other services in traffic payments as well as money circulation whose operations are in accordance with Islamic principles (Law No. 10/1998). Unlike other conventional banks, Islamic banks prohibit the existence of interest in economic activities because sharia banks adhere to the principles in Islam. The prohibition of usury or interest in economic activity is contained in Al-qur'an surat al Baqarah verses 275 - 276. This means "People who eat (take) usury can not stand but like the establishment of people who conceded devils because of (pressure) disease crazy. Their circumstances are so, is because they say (opinion), actually buying and selling is the same as usury, but Allah has justified the sale and purchase and forbid usury. Those who have reached to him the prohibition of his Lord, and then continue to cease (from taking usury), So to him what he has taken first (before coming to ban); And its affairs (up to) to God. The one who returns (taking usury), Then that person is the inhabitants of their hell eternal in it. Allah destroys Riba and fosters alms and Allah dislikes every one who remains in disbelief, and always sins ".

The growth of sharia banks in Indonesia has increased significantly every year. The growth of sharia bank can be measured by one of them is by using the indicator of financing in all shariah bank in Indonesia. The development of financing in sharia banks is increasing every year. At the end of 2014 financing at Islamic banks increased from Rp 184,122 Billion, or Rp 8,008 Billion or an increase of $8.15 \%$ to $\mathrm{Rp} 199,130$ Billion. In the middle of 2015, financing in sharia banks increased, from $\mathrm{Rp}$ 199,330 billion to Rp 4,564 billion, or increased by $2.28 \%$ to $\operatorname{Rp} 203,894$ billion.

The growth of financing in sharia banks is dominated by financing with a murabahah scheme. This shows that people in Indonesia still tend to be consumptive in their economic transactions. In 2015, murabahah financing reached $\mathrm{Rp} 117,777$ billion, the financing of musyarakah contracts reached $\mathrm{Rp} 54,672$ billion, and the financing of mudharabah contracts reached Rp 14,388 billion. Based on this data, the amount of murabahah financing is the more dominant financing in Indonesian shariah banking compared with other financing products. Mudharabah has the least amount of use compared to Murabahah financing. It is expected that Indonesian Muslims can incline more towards productive than towards consumptive.

In terms of earning volatility, we have found evidence that Islamic banks have more volatile earnings than their conventional counterparts. Several reasons might explain why Islamic banks are less stable and have more volatile earnings than conventional banks in larger 
samples. First, the profit and loss sharing instruments such as Musharaka and Mudaraba are considered to be very risky, especially in the context of information asymmetries. Second, Islamic banks lack a standardised and transparent regulatory framework, though several regulatory organisms have been established to fill the gap of regulation. Third, there is a wide consensus that Islamic banks are diverging from the rules originally set for them, especially in countries where both banking systems exist. At a theoretical level, Islamic banks should endorse equity participation as the core of the Islamic financing mode. However, at the practical level, commercial activities or non-profit and loss sharing instruments such as Murabaha and Ijara are considered to be the cornerstone of the Islamic banking system. This weak form of Islamic finance, i.e. mimicking the commercial activities of their conventional counterparts in countries where both bank types operate, sheds doubts on the entire industry which might negatively affect their reputation in Western countries and eventually make them exposed to the same risk and earnings volatility as their conventional peers in those countries (Bitar, 2017).

For example, under the classic concept of mudaraba, there are two parties; one with capital (i.e. financier or silent partner), and one with know-how (working partner) that provide labour and entrepreneurship for the completion of a project. The financier provides the capital and the entrepreneur has the ultimate control over the project. If the project is profitable then the two parties share the profits at a prearranged ratio, whereas in the case of losses, the entire loss is borne exclusively by the financier. In the case of Islamic banking, an intermediary (i.e. the bank) comes into the concept to create a triangle. Investors deposit their funds at the bank, and the bank finances projects put forward by the entrepreneurs. In this arrangement, the investor is essentially a sleeping partner who provides capital and then shares the profit or absorbs the loss. The entrepreneur must present a good proposal, and convince the financier that it is viable and profitable, etc. Consequently, the bank has a dual role. When the bank accepts funds from an investor, it becomes an entrepreneur; and when it finances a project, it becomes the financier (Doumposa, 2017).

The high amount of mudharabah financing in sharia banks depends on several factors. The factors that affect mudharabah financing include funds collected from the community or third party funds (DPK), Total Capital (CAR), and non-performing financing (NPF). The growth of financing in sharia banks is influenced by DPK. According to research wardiantika (2014), third party funds or DPK have a positive influence on the high low growth of financing.
Based on sharia banking statistical data, in 2014, the growth of third party funds increased again, which was originally in 2013, when the amount of third party funds only reached Rp 183,534 Billion up by Rp 34,324 Billion rupiah, or rose about $18.70 \%$ to $\mathrm{Rp} 217,339$ Billion. In 2015, third party funds reached $\mathrm{Rp} 231,175$ Billion.

The prohibition of interest means that Islamic banks cannot incur or earn interest in their financial transactions. Hence, they cannot issue interest-bearing loan contracts or take interest-bearing deposits. Rather, Islamic banks mobilise funds on bases that differ from those of conventional banks, and use distinct financing mechanisms in their application of funds. In their mobilisation of funds, Islamic banks currently depend on four main sources of funds that constitute their capital structure. These are the shareholders' equity, current accounts, investment accounts and savings accounts (Deehani, 1999). The minimum capital requirements recommended by the Basel Committee apply to conventional banks and do not make any allowance for Islamic banks. However, the Islamic Financial Services Board (IFSB), the Islamic equivalent of the Basel Committee, is responsible for setting regulatory standards that are on par with the Basel standards for conventional banks. The Basel rules on 'capital adequacy ratio' (CAR) have become the cornerstone of safety in modern banking. A bank's CAR is computed by dividing the total capital by the total risk-weighted assets. However, unlike their conventional counterparts, defining the denominator (i.e., risk-weighted assets) of the CAR for Islamic banks is not straightforward ${ }^{3}$. This is because of the unique risk profile that Islamic banks have with respect to their products and services, which need to be Shariah-compliant. For instance, in the case of financing projects using the profitsharing investment accounts (PSIAs) and contracts (e.g., the Mudharabah and Wakala investment accounts), Islamic banks are reluctant to share losses with their customers because of the fear that the disappointed customers might move their funds elsewhere. Thus although PSIAs provide a buffer in theory, in practice Islamic banks are very sensitive to displaced commercial risk. Furthermore, the higher the level of PSIAs in the capital structure is, the higher the agency (monitoring) costs faced by Islamic banks. All else equal, and the higher agency costs will reduce the bank's expected return on assets, which in turn might induce them to increase the riskiness of their portfolios after the imposition of capital requirements (Basher,2017)

According Fauzi (2015) in Havidz (2015), as the total assets is around 5\% from the banks total assets nationally, a customer of Islamic banking is under IDR 10 million people and there is the high possibility to increase the number of customers of Islamic banks since the Indonesian productive population is increasing steadily. In the end of November 2014, there were 12 Islamic 
Commercial Banks (BUS), 22 banks of Islamic Business Unit (UUS), 163 Islamic Rural Banks (BPRS) and 2,939 branch offices. The total assets (BUS and $U U S$ ) were IDR 261,927 trillion, IDR 198,376 trillion for financing and IDR 209,622 trillion for third-party fund. The factors affecting the growth of financing other than third party funds is the amount of capital, often referred to in banking terms as the capital adequacy ratio (CAR). According to Maula (2008) and Carlson et al. (2011), CAR has a positive influence on the growth of financing.

Based on the statistical data of sharia banking, it is seen that the amount of capital in sharia banks is not like DPK data and financing which always increases every year. The data on the amount of capital has increased and the decline is fluctuating. In 2014, the amount of capital in sharia banks has increased by 2,493 billion, bringing the total capital in 2014 to 12,539 . By the end of 2015, the total capital in sharia banks has increased again by 10,870 , bringing the total capital in Islamic Banks to 23.409 billion rupiah.

The last factor affecting financing is nonperforming financing (NPF). NPF is an indicator used to indicate loss due to financing risk. The bigger NPFs show the higher level of problematic financing. The high amount of non-performing loans causes banks to be more careful in channelling financing because banks have to form reserve allowances for the elimination of large earning assets. This is supported by research by Maula (2008) and Tracey (2011) with the result of NPF research having a negative effect on financing.

According to Berger and De Young (1997) in Havidz (2015), they stated that an increase in nonperforming loans is caused by unexpected exogenous or external events such as economic slowdowns or a firms' breakdown that leads to the bad luck hypothesis. Due to past loans or non-accruing debt, the banks should deal with the additional managerial effort and expenses. Furthermore, poor senior management practices lead to non-performing loans since the internal bank is not working proportionally, namely due to bad management. It is about estimating the inter-temporal relationship between bank efficiency and NPF.

Based on sharia banking statistics, it can be seen that non-performing financing (NPF) in sharia banks is not like DPK data and financing which always increases every year. NPF data has increase and decrease fluctuations. In 2014, the NPF in sharia banks experienced a substantial increase of Rp 9,208 billion so that the NPF in 2014 reached Rp 22,099 billion. By the end of 2015, the NPFs in sharia banks again declined by $\mathrm{Rp}$ 6,962 billion, resulting in NPFs in sharia banks becoming Rp 15,137 billion. The Financial ratios of Islamic Commercial Bank and Islamic Business Unit are 15.66\% (CAR), 0.87\% (ROA), $4.86 \%$ (NPF), $94.62 \%$ (FDR) and $93.5 \%$ (OER) per November 2014 (Authority, 2015).

A Non-Performing Loan simply means that the loan cannot be repaid by the borrower. The higher NPL means the higher the payments which could not be returned. The nature of the loan contract between conventional and Islamic banks is different. In conventional banks, the interest rate applied in the loan contract is adjustable depending on overall economic performance. If the central bank increases the rate during the loan contract, then the commercial bank will increase the interest rate on the loan and the borrower does not have a say in keeping the interest rate as it was before. This certainly creates uncertainty for the borrower. This does not happen in the case of Islamic banks. In Islamic banks, each contract has different characteristics to the others. The basics of the Islamic financial contract are buy and sell, rent and profit loss sharing. The example of buy and sell is murabahah, rent is ijarah and profit loss sharing is mudharabah and musharakah. In terms of margin as the replacement of interest rate, it cannot be easily adjusted. In the case of Indonesia, among all of those types of product, murabahah still dominates the total financing conducted by Islamic banks. This contract provides a fixed margin that has to be paid by the customers. This fix means that it will not change whatsoever. For example, when the interest rate for a loan in conventional bank increases due to the increase of the interest rate by central bank, then the bank can easily adjust it. In this case, the customers are at a disadvantage since they have to pay a higher margin. Meanwhile, for Islamic banks, although the interest rate for the loan increases, the margin of murabahah cannot be increased. Once the bank does so, the contract will be invalid. Therefore, the customers only pay the margin as stated at the beginning of the contract. This might be the reason of why the timing of the sudden increase in interest rate for conventional banks happened earlier (not at the same time) than that in Islamic banks. This is because conventional banks can easily adjust the interest rate that requires the customers to pay more. Meanwhile, the murabaha takes a much longer time to increase its NPF (sukmana,2015).

\section{RESEARCH METHOD}

The research approach used was a quantitative approach that was done by using the numbers in the 
statistical tools in the form of eviews which were then analysed using the Ordinary Least Square (OLS) analysis tool. The population and Sample in this research is the amount of Mudharabah financing, third party funds (DPK), Total Capital and Non Performing Financing (NPF) at sharia commercial banks in 2011 - 2015.

In this study, the data collected was analysed using multiple regression analysis commonly called Ordinary Least Square (OLS). The technique of data analysis was done using multiple linear regression analysis having previously done a classical assumption test first.

\section{RESULTS}

\section{Results of OLS Analysis Testing Measurements}

Mudharabah financing is considered to have greater risks compared to other financing. In the mudharabah contract, the bank provides $100 \%$ of the capital requirement while the entrepreneur provides business management services. As shahib al-mal, banks are not allowed to interfere in the day-to-day activities of business management. The results obtained from the managed business are divided between banks and business managers in accordance with the mutually agreed portion. In the event of a loss, the loss of the money is borne in whole or in part by the bank, while the manager does not get paid from his business. This high risk is why the composition of the distribution of funds to the community is more in the form of trade financing (murabaha), compared to the form of capital participation (mudharabah), which has a direct impact on economic growth in the form of new business opportunities, new employment, and the increase in the income of the population which is the nature of cooperation that is mudaraba. In Indonesia, the growth rate of mudharabah financing is still very small compared to other financing growth.

Earning financing in Indonesia does have the smallest contribution to musyarakah financing contracts and murabahah financing, but the mudharabah financing agreements each year has increased significantly. Mudharabah financing from 2011 to 2015 has increased. In 2011, the average increase in financing by Mudharabah contract each month was approximately $0.5 \%$. In early 2012, financing with Mudharabah contracts decreased from January to March 2012.

In April up to the end of 2012, Mudharabah financing again increased slightly. The decline again occurred in the month of August 2014. The decline in August 2014 resulted in instability in the months that followed. In November 2014 the decline in mudharabah financing contracts occurred continuously until April 2015. This decrease was caused by inflation in 2014 which reached $8.36 \%$. High inflation resulted in a decrease in the interest of entrepreneurs to borrow capital in banks. The test results of each variable indicate that normality, multi-collinearity, heteroscedasticity, and autocorrelation. F test can be done by comparing the $\mathrm{F}$ value with the $\mathrm{F}$ table value, basically indicating whether DPK, CAR, NPF, and SWBI influence murabahah financing at sharia commercial banks by using a significance level equal to $5 \%$. Based on the results of the Test $\mathrm{F}$ in the above table, it obtained that it is 84.66968> 2.77 , so $\mathrm{H0}$ is rejected at the level of significance of $5 \%$. It can be concluded that the independent variables (Third Party Fund (DPK), Total Capital (CAR) and NonPerforming Financing (NPF) significantly simultaneously affect the dependent variable of $Y$ (Mudharabah Financing). The $\mathrm{T}$ test was done to know the influence of each independent variable (partially). Based on the results of data processing research, the obtained $t$ count of 3.874726 larger than the t table of 2.00324 meant that $\mathrm{H} 0$ was rejected at a $5 \%$ level of significance. The conclusion is variable; Third Party Fund (DPK) has a significant positive influence on Mudharabah Financing. Based on the results of the data processing research, the obtained t count of 0.026481 is smaller than the table of 2.00324. The H0 received a significance level of $5 \%$ so the conclusion is variable. Total Capital (CAR) has no significant positive effect on Mudharabah Financing. Based on the results of the data processing research, the obtained $t$ count of 3.641613 is greater than the $t$ table of 2.00324. H0 received a significance level of $5 \%$ so the conclusion is variable; Non-Performing Financing (NPF) has a significant influence on Mudharabah Financing.

\section{B. DISCUSSION}

The hypothesis which reads Ha1 = "Third Party Fund (DPK) effect on mudharabah financing", has been accepted. The results of this study are in line with Arianti's (2011) research that examines the effect of DPK, CAR, NPF and ROA on the financing of the Bank Muamalat, in Indonesia, where the results prove that deposits have a significant positive relationship towards financing. Similarly, research by Maryanah (2008) found similar; the result proves that DPK has a positive influence on financing and Profit Sharing. The results in this study are also in line with Maharani (2010) who examined the Bank Muamalat Indonesia and found that DPK has a positive influence on financing.

Much of the research shows that deposits have a positive effect on financing. Third Party Funds are one of the most important indicators in a bank because the larger the funding source is, the more the bank will channel 
financing. This is because one of the goals of the bank is to get profit, so the bank will not be idle with funds just like that. Banks tend to channel funds as much as possible in order to obtain maximum profit as well.

The second hypothesis which reads $\mathrm{Ha} 2=$ "Number of Influential Capital on Mudharabah Financing", has been rejected. The result of the research shows that there is no significant and positive influence of Capital Adequacy Ratio towards Mudharabah Financing. This is in line with the research conducted by Arianti (2011) who found that CAR has no positive effect on financing. The results of this study are not in line with the study conducted by Maharani (2010) who studied at Bank Muamalat Indonesia, where the results prove that CAR has a positive influence on financing. Similarly, it is contrary to Giannini's (2012) research results that support the finding that CARs have an effect on Mudharabah financing at Sharia (Islamic) Commercial Banks in Indonesia; the results were found to have a positive relationship.

The results indicate that the amount of Capital has no significant effect on Mudharabah Financing. The amount of capital cannot be used to predict the distribution of financing because of the partial test results that show no significant effect between this variable with the distribution of financing. This difference is probably due to the difference in the sample used. Although the results are insignificant, it does not mean that banks can ignore the variable amount of capital in channelling financing because the adequacy of bank capital is often disrupted due to excessive financing disbursement. In addition, Mudharabah Financing is the financing that contributes the least when compared with other types of financing. The amount of capital does not affect Mudharabah financing but it can still have an effect on other types of financing, so banks cannot ignore the variable amount of capital.

The third hypothesis which reads $\mathrm{Ha} 3=$ "Non Performing Financing (NPF) affects mudharabah financing", has been accepted. The results of this study are in line with the results of the research conducted by Maula (2009) at Bank Syariah Mandiri, where the results prove that NPF has a significant positive relationship towards financing. However, this is contrary to the research conducted by Arianti (2011) who studied at Bank Muamalat Indonesia, where the results found that NPF has no effect on financing. These results are also in line with the findings of the research conducted at Sharia Commercial Banks, where the results prove that NPF has no effect on financing. The results of this study also do not support the findings of Wardiantika and Kusumaningtias (2014) who found that NPF has a negative relationship towards financing at Sharia Commercial Banks.
In principle, NPF should have a negative effect on mudharabah financing, as all banks want the highest amount of financing with the lowest risk level so all banks expand their financing as much as possible and push down the NPF number to the smallest possible. However, this is very difficult to achieve, because if you want the highest amount of financing for the community then it should be prepared to face the greater risk as well. In the end, a high increase in financing will be followed by an increase in NPF as well and vice versa. The NPF is expected to have a negative effect on the amount of financing but the presentation of the data actually shows a positive effect; if NPF is high it will produce a high amount of financing. High NPF will reduce the amount of capital and the profitability of the bank, so if high NPF happens then the bank will raise the amount of financing more for bank profits that are not reduced otherwise.

\section{CONCLUSION}

Based on the analysis of the results and discussion in this study, it can be concluded as follows:

1. Third Party Funds have a positive influence on the variable amount of mudharabah financing

2. The amount of capital has no effect on the variable amount of mudharabah financing

3. NPF has a positive influence on variable amount of mudharabah financing

\section{REFERENCES}

[1] Al-Qur'an dan Al-Karim

[2] Al-Deehani. Talla, Rifaat Ahmed Abdel Karim, Victor Murinde. 1999. The Capital Structure Of Islamic Banks Under The Contractual Obligation Of Profit Sharing. International Journal of Theoretical and Applied Finance Vol. 2, No. 3 (1999)

[3] Arianti. Wuri. 2011. Analisis Pengaruh Pengaruh Dana Pihak Ketiga (DPK), Capital Adequacy Ratio (CAR), Non Performing Financing (NPF) dan Return On Asset (ROA) Terhadap Pembiayaan Pada Perbankan Syariah" (Studi kasus Bank MuamalatIndonesia)http://eprints.undip.ac.id/32 445/1/jurnal_wuri.pdf

[4] Basher, S.A., Kessler, L.M. \& Munkin, M.K., Bank Capital and Portfolio Risk Among Islamic Banks, Review of Financial Economics . 2017 
[5] Doumposa, Michael , Iftekhar Hasanb, Fotios Pasiourasa. Bank overall financial strength: Islamic versus conventional bank. Elsevier, 2017

[6] Ghozali, Imam. Aplikasi Analisis Multivariate dengan program IBM SPSS 21 Update PLS Regresi (Edisi 7). Semarang: Badan Penerbit Universitas Diponegoro, 2013

[7] Giannini, Nur Gilang. Faktor yang Mempengaruhi Pembiayaan Mudharabah pada Bank Umum di Indonesia. Accounting Ananlysis Journal. Semarang: Universitas Negeri Semarang Indonesia, 2012.

[8] Havidz, Shinta Amalina Hazrati. Chandra Setiawan. Bank Efficiency And Non- Performing Financing (Npf) In The Indonesian Islamic Banks. Asian Journal of Economic Modelling, 2015,3 (3): 61 - 79, 2015

[9] Maharani, Sagita Devi. "Analisis Pengaruh CAR, NPF dan DPK Terhadap Penyaluran Pembiayaan (Studi Bank Muamalat Indonesia Periode 2001-2009)". Skripsi Program S1 Manajemen Universitas Diponegoro Semarang. Semarang, 2010

[10] Maryanah. Faktor-Faktor yang Memepengaruhi Pembiayaan Bagi Hasil di Bank Syariah Mandiri. Jurnal Ekonomi Keuangan dan Bisnis Islami, vol.4, No.1, 2008

[11] Maula, Khodijah Hadiyyatul. Pengaruh Simpanan (Dana Pihak Ketiga), Modal Sendiri, Marjin Keuntungan, Dan NPF (Non Performing Financing) Terhadap Pembiayaan Murabahah Pada Bank Syariah Mandiri. Skripsi. Yogyakarta: Universitas Negeri Sunan Kalijaga, 2008

[12] Pratami, Wuri Arianti. Analisis Pengaruh Dana Pihak Ketiga (DPK), Capital Adequacy Ratio (CAR), Non Performing Financing (NPF) dan Return On Assets (ROA) terhadap pembiayaan pada bank umum syariah, 2011

[13] Pratin dan Akhyar Adnan. "Analisi Hubungan Simpanan, Modal Sendiri, NPL, Prosentase Bagi Hasil, dan Mark Up Keuntungan Terhadap Pembiayaan pada Perbankan Syariah (Studi kasus pada BMI)". Dalam Sinergi Kajian manajemen dan Bisnis, Edisi Khusus on Finance. Yogyakarta: Balai, 2005
[14] Sukmana Raditya. Determinants of Non Performing Financing in Indonesian Islamic Bank. IRTI Working Paper 1436, 2015

[15] Tim Pengembangan Perbankan Syari'ah Institut Bankir Indonesia. Bank Syar'ah: Konsep, Produk dan Implementasi Operasional, Jakarta: Djambatan, 2001

[16] Undang-undang Perbankan Syariah 2008. Jakarta: Sianar Grafika, 2008

[19] Wardiantika, Liftstin dan Rohmawati kusumaningtias. Pengaruh DPK, CAR, NPF, dan SWBI terhadap Pembiayaan murabahah pada Perbankan Syariah Tahun 2008 -2012. Jurnal Ilmu Manajemen.Vol. 2 No. 4, Oktober 2014 Halaman. 311-320, 2014

[20] Wibisono, Dermawan, Riset Bisnis, Yogyakarta: BPFE. 2000

[21] www.bi.go.id. Statistik Perbankan Syariah Indonesia 2011-2016. Diunduh pada 19 Agustus 2016 